\title{
Quinto Tiberio Angelerio and New Measures for Controlling Plague in 16th-Century Alghero, Sardinia
}

\author{
Raffaella Bianucci, Ole Jørgen Benedictow, Gino Fornaciari, and Valentina Giuffra
}

Plague, a zoonotic disease caused by the bacterium Yersinia pestis, has been responsible for at least 3 pandemics. During 1582-1583, a plague outbreak devastated the seaport of Alghero in Sardinia. By analyzing contemporary medical texts and local documentation, we uncovered the pivotal role played by the Protomedicus of Alghero, Quinto Tiberio Angelerio (1532-1617), in controlling the epidemic. Angelerio imposed rules and antiepidemic measures new to the 16th-century sanitary system of Sardinia. Those measures undoubtedly spared the surrounding districts from the spread of the contagion. Angelerio seems to have been an extremely successful public health officer in the history of plague epidemics in Sardinia.

$\mathrm{T}$ he Black Death, a huge wave of epidemics of bubonic plague, spread across Europe during 1347-1353 CE. As detailed in nearly 200 local mortality studies relating to southern and western Europe, at least half of the population died of plague (1). The Black Death (1346-1353 CE) was the first outbreak of the second plague pandemic that occurred repeatedly until 1750 CE. Most likely it originated in the old plague reservoir (i.e., wild rodents) stretching from the northwestern shores of the Caspian Sea into southern Russia. Russian and Byzantine chroniclers mention the outbreak of terrible diseases there in spring 1346.

Kaffa, the far-outlying Italian trading station in Crimea, also was a source of infection. During spring 1347, Italian galleys fleeing Kaffa brought infection to Constantinople, where the plague began raging in the summer. From Constantinople, ships carried plague to ports along the Mediterranean littoral whence the infection fanned out from several epicenters, acquiring new momentum from these new centers as it spread (1).

Author affiliations: University of Turin, Turin, Italy (R. Bianucci); University of Oslo, Oslo, Norway (O. Jørgen Benedictow); and University of Pisa, Pisa, Italy (R. Bianucci, G. Fornaciari, V. Giuffra)

DOI: http://dx.doi.org/10.3201/eid1909.120311
Stimulated by earlier observations that epidemic diseases were transported by ships, the notion of quarantines began being developed in the early 14th century. Accordingly, a genuine quarantine was set up in 1377 in the Venetian trading station at Ragusa (present-day Dubrovnick, Croatia). Thirty-day isolation was imposed for ships from areas that were infected or suspected of being infected and 40-day isolation for land travelers from these areas $(2,3)$.

During the 15th and 16th centuries, quarantine and sanitary cordons were imposed. Contacts and trades with infected regions were banned, and towns' gates and states' frontiers were closed, which prevented free movement of humans and merchandises to avoid the risk of spreading the contagion (4).

The first lazaretto (plague hospital/infirmary) was set up in 1423 in Venice. This institution soon became a model for isolating infected patients and preventing the spread of the epidemics (3). The lazaretto reflected the development of epidemiology and increasing administrative skills in Renaissance society.

During $1350-1520, \approx 100$ plague tracts were published (5). They shared a view of epidemic diseases: the final cause was God's anger over his human subjects' sins, and epidemic disease was His punishment. The means of punishment, the pathogenic causal agent, was miasma, a notion of Greek Hippocratic-Galenic medicine $(2,6)$. Miasma was corruption or pollution of the air by noxious vapors containing poisonous elements caused by rotting putrid matter. Medieval medical theory added geophysical and astrologic elements; miasma also could be let out from the ground by volcanic activity or particular constellations of planets. Miasma was spread by wind and therefore could spread speedily; it could enter humans by inhalation or through the pores of the skin.

The theory was that miasma was the only cause of epidemic disease. The variety of epidemic diseases and their 
clinical and epidemiologic manifestations were explained by miasma's ability to evolve into agents with different pathogenic properties, so a mild disease could develop into plague. According to miasmatic theory, plague patients were contaminated by the most dangerous type of miasma; air of the room also was contaminated by it (6).

The plague tracts warned all persons, including physicians, not to enter the rooms of plague patients or perform clinical examinations of such patients. Patients should be contacted from a distance. Thus, clinical elements mentioned in plague tracts were not empirical observation but based on hearsay. Some of this hearsay was consistent, especially that plague buboes developed in plague patients; most often these were visible on the neck because patients were not physically examined.

Not until the Renaissance, in the decades around 1500, was the theory of miasma expanded to include the idea that healthy persons could be infected by touching infected persons or objects contaminated by them with miasma (fomites), the Fracastoro miasmatic-contagionistic theory of cross-infection and epidemic spread (1-6). The basic tenets of miasmatic-contagionistic theory governed the actions and epidemic countermeasures of governments and municipal councils and their medical advisers. This theory explains why measures such as quarantines, sanitary cordons, isolation of persons with and suspected to have plague and with objects used by them, disinfection of houses, and disinfection of textiles were implemented beginning in the early 1500 s.

Consequently, through special laws, administrative institutions were created to manage the organization of the sanitary system during plague outbreaks. The most efficient system of prevention and control was established in north-central Italy by the cities of Venice, Genoa, Florence, and Milan during the 14th and 15th centuries (2-4).

However, in Sardinia, early Modern Age (late 14thearly 15 th centuries) health systems were considered mediocre $(7,8)$. From the arrival of the Black Death in Sardinia (in 1348), plague epidemics required day-by-day organization. No social or political measures were pursued to control and prevent the plague outbreaks.

Despite the lack of organization in the Sardinian health system, in 1455, King Alfonso V of Aragon (1396-1458) established and imposed improvements. The royal ordinance created and imposed the so-called Office of the Protomedicus of the Sardinian Reign in Cagliari. Although this institution was already operating in the Catalan-Aragonese region, it represented an innovation for the island. The Protomedicus, a person belonging to the upper class and possessing a medical degree, superintended the medical practice and selected persons to certify to perform as physicians. Together with the municipal authorities, the Protomedicus coordinated prophylaxis and therapies (8).
The Catalan-Aragonese sanitary system of the second half of the 15th century had a Health Guard or Plague Guard, also called Morber. A Morber was also installed in Sardinia at that time $(8,9)$. The Morbers' task was to watch over the sanitary conditions of the ships docking at the island's harbors by halting the disembarkation of persons with or suspected to have plague and to assist the Protomedicus during the plague outbreaks.

During the 15th and 16th centuries, Sardinian literature that focused on the history of medicine was poor and attests to the extreme backwardness of the medical culture and the sanitary structures (8). During the 16th and 17th centuries, only a few qualified physicians, selected by the Protomedicus, were practicing in Sardinia (8). Because of the absence of local universities, upper class students willing to perform medical studies completed their education in universities in Spain or Italy and seldom returned to Sardinia (10). Even after the foundation of the Universities of Sassari (1617) and Cagliari (1626), the situation remained almost unchanged because a rigorous faculty of medicine was still lacking (10).

The deficient professional background of the Sardinian physicians was reflected in poor communal organization of the sanitary structures. Those limits affected any attempt to prevent and contain the plague outbreaks that lashed the island from the time of the Black Death onward $(8,11,12)$.

We report on the Neapolitan physician Quinto Tiberio Angelerio (13,14), Protomedicus of Alghero, who provided a breakthrough in the fight against the 1582-1583 plague epidemic by introducing novel prophylactic measures. Angelerio's scientific background was influenced by Galen's miasmatic theories and by Fracastoro's contagionistic theories $(2,3)$. In addition, Angelerio had experience with plague before coming to Alghero. He had practiced in Messina, Sicily, during the 1575-1576 plague epidemic. At that time (1575), the Protomedicus of the Sicilian Reign, Giovanni Filippo Ingrassia (1510-1580), was successfully battling the plague outbreak that was spreading in Palermo (15).

Ingrassia had introduced useful prevention measures against plague, which included the isolation of persons with and suspected to have plague and of convalescents in 3 different isolation centers; the disinfection of the houses in which plague-related deaths had occurred; and use of dry heat to eliminate the "seeds of contagion" from everyday objects, thus anticipating the concept of modern sterilization $(15,16)$.

No historical sources provide evidence of direct contact between the 2 physicians. Nonetheless, Angelerio's observations in Sicily formed his notions of how to combat such epidemics (8). To stem the spread of the contagion, Angelerio established a set of sanitary and prophylactic instructions that showed strong analogies with those previously adopted by Ingrassia (8). 


\section{Historical Sources and Demographic Data}

Using contemporary documents, we reconstructed the measures introduced by Angelerio and the city government to prevent and control plague epidemics (17). The history of the 1582-83 epidemic, which lasted 8 months, is detailed in Ectypa Pestilentis Status Algheriae Sardiniae (Instructions on the Alghero, Sardinia, Plague Epidemic) (p. 110) (17) (Figure 1). Angelerio wrote and dedicated the booklet, published in 1588 in Cagliari, to the Viceroy De Moncada $(17,20)$. Two printed versions and a manuscript are extant. The 1588 edition was written in Latin with a 12-page addendum in Catalan entitled Instructions del Mates Autor (Instructions from the same author). The second edition, published in Madrid in 1598, was entitled Epidemiologia sive Tractatus de Peste (Epidemiology or Treatise on Plague) and was written exclusively in Castilian $(18,20)$. A copy of each edition is kept in the University Library of Cagliari, and 1 copy of the Ectypa is preserved at the Alghero's Municipal Library (19). The detailed sanitary measures formulated in Ectypa included 57 instructions (Table 1, Appendix, wwwnc.cdc.gov/EID/article/19/9/120311-T1.htm). In the Epidemiologia, the number of instructions was reduced to 30 .

The paucity of contemporary documentary records and the discrepancies between their information made a death rate difficult to estimate (20-25). Death registers were kept only from 1677 onward (21-23).

The archival data presented below are from notepads belonging to the Archives of the Diocesan Curia of Alghero (ACVA Battesimi) (21-23) (Table 2). Because of the absence of burial registers for this period and a nearly 4-year gap (November 26, 1581-November 10, 1584) in marriage registers, the demographic reconstruction of the population's profile has to be based only on baptismal registers $(21,23)$. In 1582 , a total of 158 children were baptized (Table 2). When we account for the annual mean of 154 baptisms in the 5 previous years (1577-1581) and the fact that the effects of the plague epidemic on the population can be estimated only for the following year (1583), the monthly distribution of baptisms in 1582 appears to be normal: unaffected by plague $(21,23)$.

In 1583 , the number of baptisms fell by $59.7 \%$ to 62 . In 1584 , the number of baptisms increased sharply to 173 , $12.3 \%$ above the average for $1577-1581$, indicating the immediate onset of recuperative population growth in the wake of the plague epidemic. This growth resulted from a strong increase in marriages and consequent increase in conceptions and births because young adults could easily find jobs and housing vacated because of the plague and, for the same reason, immigration by young adults into the town from the surrounding countryside $(1,6,21,23-26)$.

The bibliographer and diplomat Toda y Güell (27) claimed that the 1582-1583 outbreak caused 6.000 deaths,

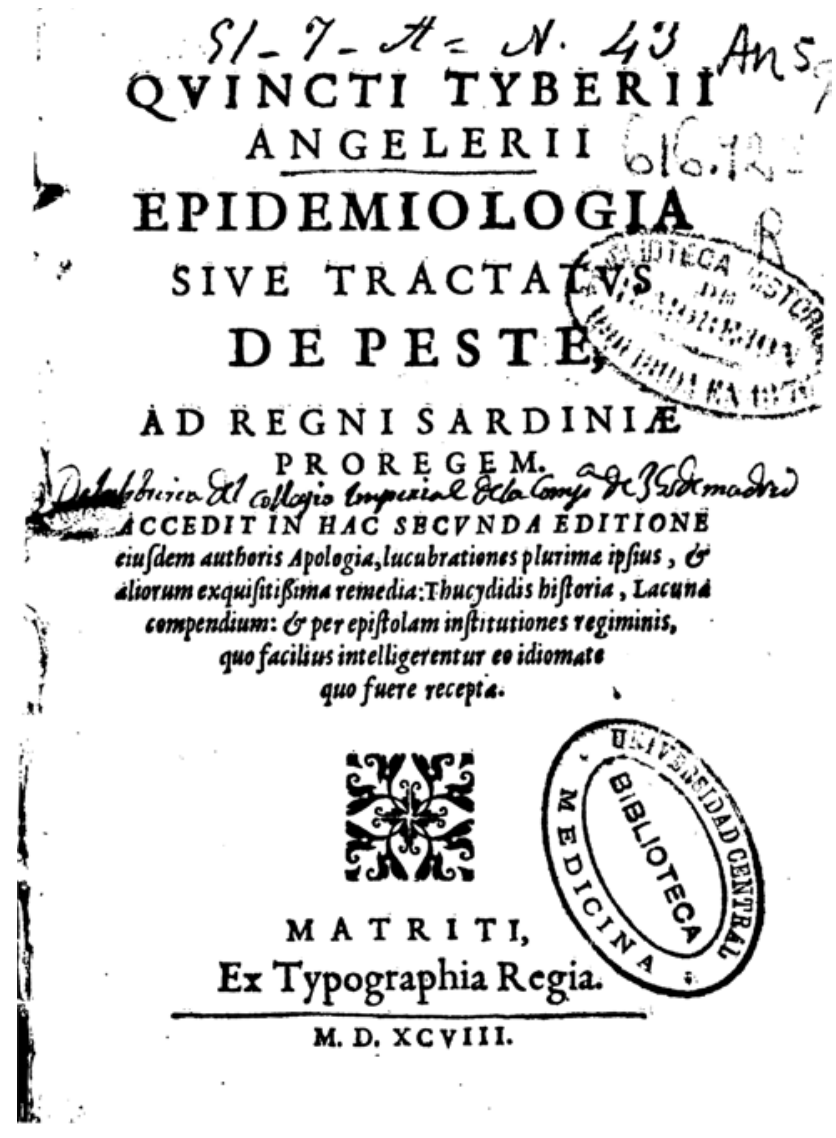

Figure 1. Frontispiece of the Epidemiologia Sive Tractatus de Peste.

and only 150 (cent y sinquanta) persons survived.According to modern demographists, it is unlikely that Alghero counted 6.000 inhabitants at the end of the 16th century $(19,21,22)$. Data from the 1589 census $(24)$ attribute to Alghero 768 fires (each fire was formed by a family of 4.5-5 persons), which correspond to $\approx 3,400-3,800$ inhabitants. Therefore, it appears that the death rate $(97.6 \%)$ was intentionally augmented by local authorities to obtain a tax reduction $(14,21,22)$.

\section{Findings and Discussion}

After the 1528-1529 outbreak, Alghero remained free of plague for $\approx 60$ years $(13,14)$ (Figure 2). The first new casualty attributed to plague in Alghero was registered on November 19, 1582 (17,19-22). The epidemic lasted 8 months and ended in June. After June 14, 1583, no new cases of contagion were registered (17).

The Protomedicus Angelerio immediately recognized the clinical manifestation of the infection (inguinal buboes and delirium) in a sailor who had disembarked from a ship docked during 1 night at the beginning of November 1582 (17). A sailor on a ship from Barcelona was thought to have been the initial harbinger of the infection (17). At that time, however, plague was almost absent from Spain while 
ravaging France. More likely the sailor disembarked from a ship coming from Marseille, where the plague had raged since 1581 (19). The Morbers had not been effective in halting the arrival of the plague (9).

After the sailor's death, 2 women, a widow named Cifra and her mother, Grazia, who was assisting her at Alghero's Sant'Antonio Hospital, died in succession. With the help of a priest, Angelerio tried to convince the Bishop, Andrea Baccallar, and the Magistrates to contain the focus of the contagion because he recognized the small punctuate bruises (petecchiae) in the 2 deceased women $(17,19)$. The Magistrates were indecisive, however, and on the morning of November 20, 1582, Bishop Baccallar asked the Senate to isolate the ill patients. However, the senators did not take Angelerio's report seriously, and Angelerio was accused of having an apocalyptic vision of the future (19). Meanwhile, the son of the widow Cifra died from plague. His death was followed by those of a crippled woman, an old woman, and a young daughter of the widow Crippa.

Because Angelerio was unable to persuade the Magistrates, he turned to the Viceroy, don Michele De Moncada $(8,17)$. Angelerio explained that the forthcoming plague outbreak would have devastating effects on the population. Furthermore, he detailed the rules and sanitary measures needed to contain the epidemic.

Convinced by Angelerio's arguments, the Viceroy De Moncada gave orders to block all commerce from and to Alghero. A triple sanitary cordon was established, and triple barriers were built around Alghero's boundaries. Horse guards checked the city walls (8).

The cessation of commerce was taken badly by the inhabitants. Angelerio was loathed by the population, who wanted to lynch him. However, when the contagion spread from the core of the old town to the whole city, Angelerio was finally entrusted with the task of containing the epidemic $(8,17)$.

Angelerio pioneered the implementation of successful public health measures in 16th-century Sardinia, basing his policies on daily reports of the Alghero population's health conditions and the incidence and location of plague cases. A general public health framework, including laws for plague control, decrees, institutions, and infrastructures was created. A system of basic welfare guaranteed by the city government was also established to satisfy the population needs in terms of medical treatment and food supplies and to implement disinfection of the houses (25). The pharmacists had to provide the poorest citizens with the necessary treatments (such as the Armenian bole, a ferruginous, ochreish, red clay used as a therapeutic substance against plague and all types of poisons). A list of the supplied treatments and a list of the citizens had to be kept to distinguish between the poorer and the richer. Richer persons would
Table 2. Monthly number of births according to the baptismal registers, Sardinia, 1582-1584

\begin{tabular}{lccc}
\hline & \multicolumn{3}{c}{ No. baptisms, by year } \\
\cline { 2 - 4 } Month & 1582 & 1583 & 1584 \\
\hline Jan & 10 & 9 & 7 \\
Feb & 12 & 13 & 11 \\
Mar & 8 & 5 & 17 \\
Apr & 16 & 3 & 15 \\
May & 20 & 2 & 20 \\
Jun & 6 & 0 & 11 \\
Jul & 12 & 6 & 16 \\
Aug & 13 & 6 & 23 \\
Sep & 21 & 7 & 20 \\
Oct & 15 & 2 & 16 \\
Nov & 17 & 4 & 7 \\
Dec & 8 & 5 & 10 \\
Total & 158 & 62 & 173 \\
\hline
\end{tabular}

pay for their treatments, and the city government would pay for paupers (Instruction XXII). The Morbers were compelled to completely disinfect the city, house after house. The darkest houses and those lacking aeration had to be whitewashed by painters who had survived the contagion. Bonfires had to be set all around. For the less suspected houses, windows were required to be kept open at all times, perfumes to be sprayed, and all surfaces washed with vinegar (Instructions LIII and XLIX). Movements of people and goods to and from the city were strictly controlled during the epidemics (17).

Angelerio's instructions and measures facilitated interventions and changed the way in which local health officers were selected. The town was divided into 10 wards. Each ward was controlled by a Health Deputy, who was invested with full authority according to the new antiepidemic health laws, and a Plague Guard (Instruction II). The Health Deputies and the Morbers gathered twice a day in the so-called "City House" to follow the course of the epidemic and to transmit the information to the Councilors who were assisted by the physicians (Instruction VI) (17).

Angelerio's health policy emphasized disease prevention through isolation of persons infected with or suspected to be infected with plague (Instructions IV, V). Persons suspected to have plague were isolated at a center (tancat) (Instruction XVIII), whereas plague patients were housed at a lazaretto (Instructions XXXI). The main city hospital, the Sant'Antonio, also served as a lazaretto to isolate the plague patients. Guards ensured isolation of the above centers (Instruction XX).

Fire had to be set to mattresses, fittings, and furniture from all houses in which cases of plague were registered (Instruction VII). When a person was suspected of having died of plague, the physicians or surgeons had to check the corps to establish whether the deceased person actually had died of plague. If the cause of the death was indeed plague, the victim's relatives carried the corpse in the courtyard or left it outside the door (Instruction X). 


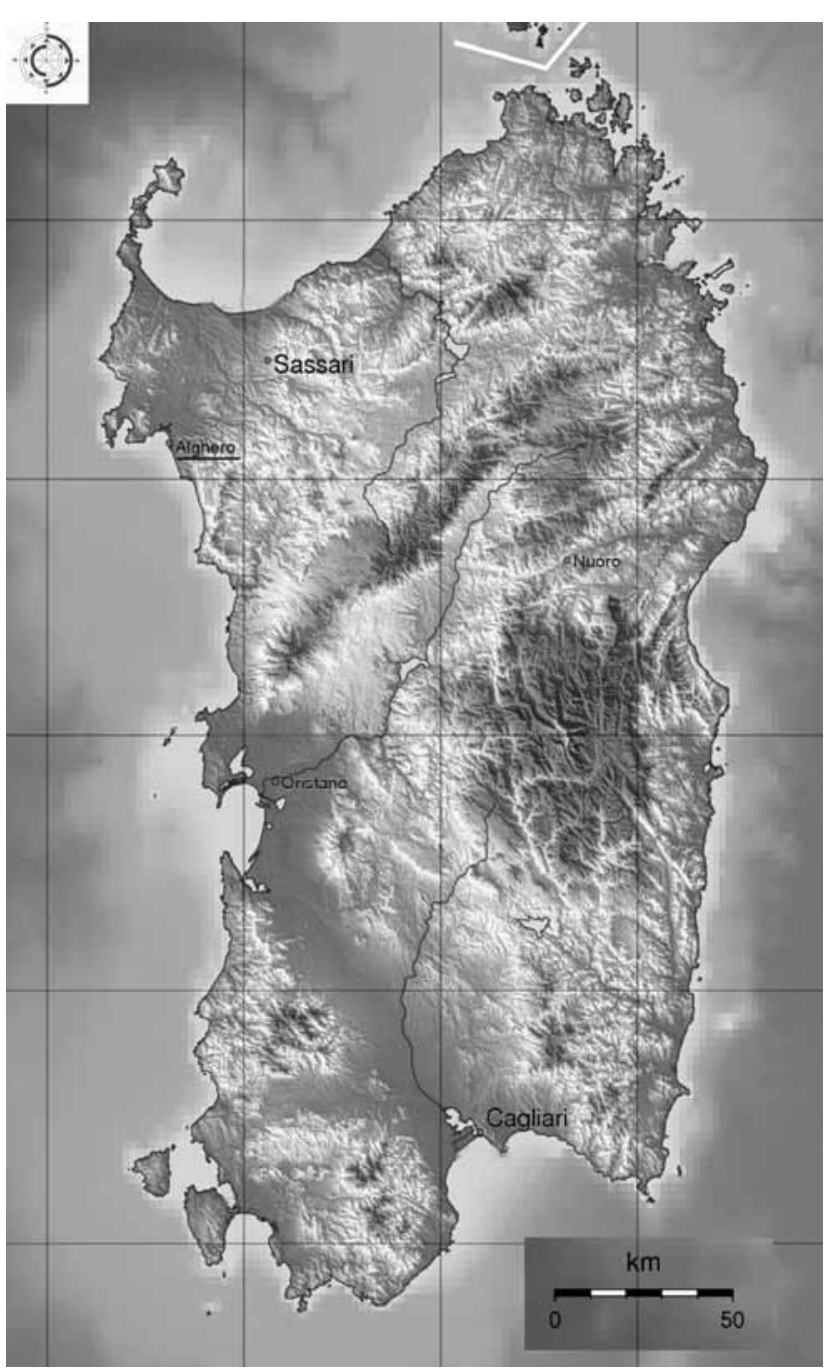

Figure 2. Modern-day Sardinia.

Plague victims were buried in secluded cemeteries within 6 hours after death; burying plague victims inside the churches was strictly forbidden. Long and deep trenches were excavated, and the corpses were covered with lime to not corrupt the air and release mephitic vapors (Instruction XXXII). Grave diggers were selected from among persons who had contracted, and survived, plague during a previous outbreak in another town. They lived separately from the rest of the community and far from the hospital and were not allowed to leave their houses unless a Health Deputy accompanied them (Instruction XII) (17).

Moreover, Angelerio introduced a new method for sterilizing clothes, textiles, and objects according to the miasmatic-contagionistic notions. Stoves/ovens similar to those used to cook the flat tiles (rejolas) were kept constantly lighted by an underlying fire (Instruction XXXIX). The stove's chamber was filled with the presumed textiles and objects after they had been washed under the Morbers' supervision (Instruction XLIV) (17).
The causative agent of plague and its vector (rat fleas) were not known scientifically until the end of the 19th century $(28,29)$. However, Angelerio clearly recognized the role of disinfection in controlling plague with dry heat to eliminate the responsible agents (which he called the malefica semina, "bad seeds"). The miasmatic-contagionistic theory implied to Angelerio that miasmatic contagion was present wherever plague patients had been. Therefore, everything they had worn or touched, as well as the place they had stayed, had to be disinfected $(3,4)$.

Through the introduction of dry heat, both the elimination of the plague bacillus (Yersinia pestis) and its vectors (the fleas) were guaranteed (30). In addition, the vectors' elimination helped prevent the transfer of infected fleas among citizens. Angelerio's intuition, which led to selection of painters and grave diggers from among persons who had already acquired and survived plague, anticipates the notion that semi-immunity to the bubonic form of plague may develop in long-term recovered patients (31).

During the plague outbreak in Sardinia during 1652 1657, Angelerio's instructions were resumed (20,32). The only 17th-century plague tract used in Sardinia, the Tratado Universal (Universal Tract), written by Juan Núnez de Castro in 1648, specifically refers to Angelerio's instructions. Following his instructions, Núnez de Castro ordered the establishment of sanitary cordons, quarantines, isolation centers for persons with and suspected of having plague and for convalescents, and disinfection of clothes and houses; he also ordered the following of the previously detailed rules for mortuary hygiene $(17,32)$. Núnez de Castro's booklet was reprinted in Cagliari in 1652 by the Protomedicus Antonio Galcerín with the following title: Instruccion de las Prevenciones que se Hande Disponer en Tiempo de Contagio (Instruction of the Preventive Measure that Have to be Applied during the Period of Contagion) (8). This plague guide became the sole reference for the Sardinian health authorities during the 1652-1657 outbreak that ravaged the island $(8,13,14)$.

In conclusion, Angelerio's observations and wellorganized public health services contained the epidemic in the city and halted its spread. His modern prophylactic and hygienic measures represent a successful innovation in the sanitary system of 16th-century Sardinia and in the Mediterranean area and attest to the extraordinary efforts of the city government to prevent the introduction and spread of contagion. The measures he introduced in Sardinia paved the way for subsequent generations of physicians and enabled them to manage plague epidemics more efficiently.

Support was provided by grants from the Fondazione Banco di Sardegna. 
Dr Bianucci is a postdoctoral researcher and anthropologist at the University of Turin in Italy. Her research interests focus on the history and the biology of ancient and modern plague pandemics and on other infectious diseases of the past, such as leishmaniasis and malaria.

\section{References}

1. Benedictow OJ. The Black Death 1346-1353: the complete history. Woodbridge (UK): Boydell Press; 2004.

2. Cosmacini G. Storia della medicina e della sanità in Italia. Vol. 1. 6th ed. Rome: Editori Laterza; 1994.

3. Cipolla CM. Contro un nemico invisibile. Epidemie e strutture sanitarie nell'Italia del Rinascimento. Bologna (Italy): Il Mulino; 1986.

4. Hirst LF. The conquest of plague. Oxford (UK): Oxford University Press; 1953.

5. Sudhoff K, editor. Archiv für Geschichte der Medizin. Vols. 4-9, 11, 14, 16. Leipzig (Germany): Verlag von Johann Ambrosius Barth; 1910-1925.

6. Benedictow OJ. What disease was plague? On the controversy over the microbiological identity of plague epidemics of the past. Leiden (the Netherlands): Brill; 2010. p. 341-59.

7. Pinna G. Sulla pubblica sanità in Sardegna dalle sue origini sino al 1850. Cagliari (Italy): Dessì; 1898.

8. Manconi F. Castigo de Dios. La grande peste barocca nella Sardegna di Filippo IV. Rome: Donizelli Editore; 1994. p. 12-25, 97-115 $115-28$.

9. Atzeni V. Quinto Tiberio Angelerio, insigne igienista precursore della stufa a secco. Humana Studia. 1955; Serie II, Anno VII, Supplemento Fascicolo II:11-31.

10. Turtas R. La nascita dell'università in Sardegna. La politica culturale dei sovrani Spagnoli nella formazione degli atenei di Sassari e di Cagliari (1543-1632). Sassari (Italy): Università degli Studi; 1988.

11. Tola P. Dizionario biografico degli uomini illustri di Sardegna. I. Turin: Tipografia Chirio e Mina; 1837. p. 76.

12. Floris F. La grande enciclopedia della Sardegna. Rome: Newton and Compton Editori; 2002.

13. Corradi A. Annali delle epidemie occorse in Italia dalle prime memorie fino al 1850 compilati con varie note e dichiarazioni. Vol I. Bologna (Italy): Forni Editore; 1973. p. 641-2.

14. Fara GF. De rebus sardois 1835. Sassari (Italy): Gallizzi; 1992.

15. Cappello F, Gerbino A, Zummo G. Giovanni Filippo Ingrassia: a five-hundred year-long lesson. Clin Anat. 2010;23:743-9. http://dx.doi.org/10.1002/ca.21038

16. Ingaliso L. Introduzione a GF Ingrassia: informatione del pestifero et contagioso morbo il quale affligge ed ha afflitto la città di Palermo e molte altre terre di Sicilia nel 1575-1577. Milan: Edizioni Franco Angeli; 2005.
17. Angelerii QT. Ectypa pestilentis status Algheriae Sardiniae. Ad Ill. D.D. Michaelem A. Moncada Regni Proregem etc. Calari: typ.Nic. Canelles per Franc.Guarnerium; 1588.

18. Angelerii QT. Epidemiologìa sive tractatus de peste, ad Regni Sardiniae Proregem. Madrid: ex Typographia Regia; 1598.

19. Scanu P. La Pesta de 1582-1583 a l'Alguer. L'obra de Quinto Tiberio Angelerio. Speech of the author to the Acádemia de Ciènces Médiques de Catalunya i de Balears on 3-XI-1584.

20. Budruni T. Pestilenze e ripopolamento ad Alghero nell'età Spagnola (1582-1652). Crisi e vitalità di una cultura urbana. Quaderni sardi di storia. 1985-1986; 5: 109-41.

21. Nughes A. La diocesi di Alghero nel XVI secolo, in Alghero, la Catalogna, il Mediterraneo, a cura di A. Mattone. Sassari (Italy): P. Sanna; 1994. p. 361-8.

22. Serri A. La popolazione di Alghero nell'età Spagnola (XV-XVII secolo). In: Mattone A, Sanna P, editors. Alghero, la Catalogna, il Mediterraneo-Storia di una città e di una minoranza catalana in Italia (XIV-XX secolo). Sassari (Italy): Edizioni Gallizzi; 1994. p. 361-9.

23. Nughes A. La riforma tridentina nella diocesi di Alghero sotto l'episcopato di Andreu Baccallar, Tesi di Laurea, Roma, 1980.

24. G. Due censimenti inediti dei "fuochi sardi": 1583, 1627. Archivio Sardo del Movimento Operaio, Contadino e Autonomistico. 1980;11-13:351-90.

25. Pezzi G. Una ignota opera catalana sulla peste che colpì la città di Alghero in Sardegna. Atti o memorie dell'Accademia di Storia dell'Arte Sanitaria, Istituto Nazionale Medico Farmacologico Serono, Roma; 1951. p. 81-8.

26. Biraben J-N. Les hommes et la peste en France et dans les pays Européens et Méditerranéens. Vol. 1. Paris: Mouton; 1975.

27. Toda y Güell E. L'Alguer. Un popolo catalano d'Italia. Traduzione, introduzione e note a cura di Rafael Caria. Sassari (Italy): Edizioni Gallizzi; 1888. p. 175

28. Simond PL. La propagation de la peste. Ann Inst Pasteur (Paris). 1898;12:625-87.

29. Yersin A. La peste bubonique à Hong Kong. Ann Inst Pasteur (Paris). 1894;8:662-7.

30. Perry RD, Fetherston JD. Yersinia pestis - etiological agent of plague. Clin Microbiol Rev. 1997;10:35-66.

31. Li B, Du C, Zhou L, Bi Y, Wang X, Wen L, et al. Humoral and cellular immune responses to Yersinia pestis infection in long-term recovered plague patients. Clin Vaccine Immunol. 2012;19:228-34. http://dx.doi.org/10.1128/CVI.05559-11

32. Núnez de Castro J. Tratado universal en que se declara que sea peste; de que causas provenga este contagio; con que remedias se han de prevenir sus fuerças y quales sean los antidotos con que se ha de preferuar. Madrid: Alfonso de Paredes; 1648. p. 35.

Address for correspondence: Raffaella Bianucci, Department of Public Health and Paediatric Sciences, Laboratory of Physical Anthropology, University of Turin, C.so Galileo Galilei, 22, 10126 Turin, Italy; email: raffaella.bianucci@unito.it

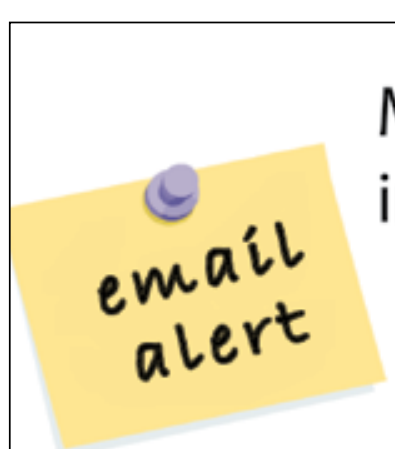

\section{Manage your email to focus on content of interest to you.}

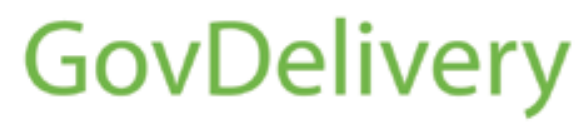

www.cdc.eid/ncidod/eid/subscribe.htm 